Annals of Pure and Applied Mathematics

Vol. 13, No. 2, 2017, 241-248

ISSN: 2279-087X (P), 2279-0888(online)

Published on 29 April 2017

Annals of

www.researchmathsci.org

DOI: http://dx.doi.org/10.22457/apam.v13n2a11

Pure and Applied

Mathematics

\title{
Some Results on Decompositions of M-Continuity
}

C.Loganathan $^{1}$, R.Vijaya Chandra ${ }^{2}$ and O.Ravi ${ }^{3}$

${ }^{1}$ Department of Mathematics, Maharaja Arts and Science College Coimbatore-641407, Tamil Nadu, India. e-mail: clogu@ rediffmail.com

${ }^{2}$ Department of Mathematics, Navarasam Arts and Science College for Women Arachalur, Erode -638101, Tamil Nadu, India. e-mail: risrchandra@gmail.com

${ }^{3}$ Department of Mathematics, P.M.Thevar College, Madurai-625523

Tamil Nadu, India. e-mail: siingam @ yahoo.com

Received 1 April 2017; accepted 26 April 2017

Abstract. In this paper, we obtain some important results of decomposition of Mcontinuity in minimal spaces. In most of the occasions, our ideas are illustrated and substantiated by suitable examples.

Keywords: m-A set, m-B set, m-t set, M-A continuity, M-B continuity, M-C continuity.

AMS Mathematics Subject Classification (2010): 54A05, 54D15, 54D30

\section{Introduction}

Njastad [13] initiated the concept of nearly open sets in topological spaces. Following this initiation, many research papers were introduced in this area $[1,5,10,11,12,16$, 17]. Many researchers like Hatir [6, 7, 8, 9], Dontchev [3] and Ganster [4] proposed decompositions of continuity in topological spaces. It is an effort based on them to bring out a work in the name of decompositions of M-continuity in minimal spaces using the new sets like $\mathrm{m}-\mathrm{A}$ sets, $\mathrm{m}-\mathrm{B}$ sets and $\mathrm{m}-\mathrm{C}$ sets and the new mappings like M-A continuous, $\mathrm{M}-\mathrm{B}$ continuous and $\mathrm{M}-\mathrm{C}$ continuous. In this paper, we obtain some important results in minimal spaces.

\section{Some basic results}

Definition 2.1. A minimal space $\left(X, m_{x}\right)$ has the property I if the any finite intersection of m-open sets is m-open.

Remark 2.1. For subsets $A$ and $B$ of a minimal space $\left(X, m_{x}\right)$ satisfying property $I$, the following holds:

$$
m-\operatorname{Int}(A \cap B)=m-\operatorname{Int}(A) \cap m-\operatorname{Int}(B) .
$$

Definition 2.2. [15] A minimal structure $m_{x}$ on a nonempty set $X$ is said to have property $\mathcal{B}$ if the union of any family of subsets belonging to $m_{x}$ belongs to $m_{x}$.

Lemma 2.1. [15] The following are equivalent for the minimal space $\left(X, m_{x}\right)$. 
C.Loganathan, R.Vijaya Chandra and O.Ravi

(i) $\mathrm{m}_{\mathrm{x}}$ have property $\mathcal{B}$.

(ii) If $\mathrm{m}_{\mathrm{x}}-\operatorname{Int}(\mathrm{E})=\mathrm{E}$, then $\mathrm{E} \in \mathrm{m}_{\mathrm{x}}$.

(iii) If $\mathrm{m}_{\mathrm{x}}-\mathrm{Cl}(\mathrm{F})=\mathrm{F}$, then $\mathrm{F}^{\mathrm{c}} \in \mathrm{m}_{\mathrm{x}}$.

Example 2.1. For subsets $A$ and $B$ of a minimal space $\left(X, m_{x}\right)$ satisfying property $\mathcal{B}$, the following does not hold:

$$
\mathrm{m}-\operatorname{Int}(\mathrm{A} \cap \mathrm{B})=\mathrm{m}-\operatorname{Int}(\mathrm{A}) \cap \mathrm{m}-\operatorname{Int}(\mathrm{B}) \text {. }
$$

Let $X=\{a, b, c, d\}, m_{x}=\{\phi, X,\{a\},\{a, b\},\{a, c\},\{b, c\},\{a, b, c\}\}$

Let $A=\{a, b\}$ and $B=\{b, c\}$. Then $A \cap B=\{b\}$.

We have $m-\operatorname{Int}(A)=\{a, b\} ; m-\operatorname{Int}(B)=\{b, c\}$ and $m-\operatorname{Int}(A) \cap m-\operatorname{Int}(B)=\{b\}$.

But $\mathrm{m}-\operatorname{Int}(\mathrm{A} \cap \mathrm{B})=\phi$. Hence $\mathrm{m}-\operatorname{Int}(\mathrm{A} \cap \mathrm{B}) \neq \mathrm{m}-\operatorname{Int}(\mathrm{A}) \cap \mathrm{m}-\operatorname{Int}(\mathrm{B})$.

\section{3. $\mathrm{m}-\mathrm{C}$ sets}

We introduce the following sets [2]:

Definition 3.1. A subset $S$ of $X$ is said to be

(i) regular $\mathrm{m}$-open if $\mathrm{S}=\mathrm{m}-\mathrm{Int}(\mathrm{m}-\mathrm{Cl}(\mathrm{S}))$,

(ii) regular $\mathrm{m}$-closed if $\mathrm{S}=\mathrm{m}-\mathrm{Cl}(\mathrm{m}-\mathrm{Int}(\mathrm{S}))$.

The family of all regular $\mathrm{m}$-closed sets of $\mathrm{X}$ is denoted $\mathrm{m}-\mathrm{RC}(\mathrm{X})$.

Definition 3.2. A subset $S$ of $X$ is said to be

(i) a m-A set if $\mathrm{S}=\mathrm{M} \cap \mathrm{N}$ where $\mathrm{M}$ is $\mathrm{m}$-open and $\mathrm{N} \in \mathrm{m}-\mathrm{RC}(\mathrm{X})$,

(ii) a m-t set if $\mathrm{m}-\operatorname{Int}(\mathrm{m}-\mathrm{Cl}(\mathrm{S}))=\mathrm{m}-\mathrm{Int}(\mathrm{S})$,

(iii) a m-B set if $\mathrm{S}=\mathrm{M} \cap \mathrm{N}$ where $\mathrm{M}$ is $\mathrm{m}$-open and $\mathrm{N}$ is a $\mathrm{m}-\mathrm{t}$ set,

(iv) a m-h set if $\mathrm{m}-\operatorname{Int}(\mathrm{m}-\mathrm{Cl}(\mathrm{m}-\operatorname{Int}(\mathrm{S})))=\mathrm{m}-\mathrm{Int}(\mathrm{S})$,

(v) a m-C set if $\mathrm{S}=\mathrm{M} \cap \mathrm{N}$ where $\mathrm{M}$ is $\mathrm{m}$-open and $\mathrm{N}$ is a $\mathrm{m}-\mathrm{h}$ set.

Example 3.1. Let $X=\{a, b, c\}$ and $m_{x}=\{\phi, X,\{a\},\{b\},\{a, b\}\}$.

Then the sets in $\{\phi, X,\{b, c\},\{a, c\},\{c\}\}$ are called $m_{x}$-closed.

Example 3.2. Let $X=\{a, b, c\}$ and $m_{x}=\{\phi, X,\{a\},\{c\},\{a, b\},\{a, c\}\}$. Then the sets in $\{\phi, X,\{b, c\},\{a, b\},\{c\},\{b\}\}$ are called $m_{x}$-closed.

Example 3.3. Let $X=\{a, b, c\}$ and $m_{x}=\{\phi, X,\{a, b\},\{b, c\}\}$. Then the sets in $\{\phi, X,\{c\},\{a\}\}$ are called $m_{x}$-closed.

Remark 3.1. It is evident that any $m$-open set of $X$ is an $m$ - $\alpha$-open and each $\mathrm{m}$ - $\alpha$-open set of $\mathrm{X}$ is both $\mathrm{m}$-semi-open and $\mathrm{m}$-preopen. But the separate converses are not true.

Theorem 3.1. If $A$ and $B$ are two $m-t$ sets of a space $X$ satisfying property I, then $A \cap$ $\mathrm{B}$ is a $\mathrm{m}-\mathrm{t}$ set in $\mathrm{X}$.

Proof: Since $A \subseteq \mathrm{m}-\mathrm{Cl}(\mathrm{A})$,

$$
\mathrm{m}-\operatorname{Int}(\mathrm{A} \cap \mathrm{B}) \subseteq \mathrm{m}-\operatorname{Int}(\mathrm{m}-\mathrm{Cl}(\mathrm{A} \cap \mathrm{B}))
$$


Some Results on Decompositions of M-Continuity

$$
\begin{aligned}
& \subseteq \mathrm{m}-\operatorname{Int}(\mathrm{m}-\mathrm{Cl}(\mathrm{A}) \cap \mathrm{m}-\mathrm{Cl}(\mathrm{B})) \\
& =\mathrm{m}-\mathrm{Int}(\mathrm{m}-\mathrm{Cl}(\mathrm{A})) \cap \mathrm{m}-\mathrm{Int}(\mathrm{m}-\mathrm{Cl}(\mathrm{B})) \\
& =\mathrm{m}-\mathrm{Int}(\mathrm{A}) \cap \mathrm{m}-\mathrm{Int}(\mathrm{B})(\text { since } \mathrm{A}, \mathrm{B} \text { are } \mathrm{m}-\mathrm{t} \text { sets }) \\
& =\mathrm{m}-\operatorname{Int}(\mathrm{A} \cap \mathrm{B}) .
\end{aligned}
$$

Thus $\quad \mathrm{m}-\operatorname{Int}(\mathrm{m}-\mathrm{Cl}(\mathrm{A} \cap \mathrm{B}))=\mathrm{m}-\operatorname{Int}(\mathrm{A} \cap \mathrm{B})$ and $\mathrm{A} \cap \mathrm{B}$ is $\mathrm{m}-\mathrm{t}$ set.

Theorem 3.2. If $\mathrm{A}$ is a m-t set of $\mathrm{X}$ and $\mathrm{B} \subseteq \mathrm{X}$ with $\mathrm{A} \subseteq \mathrm{B} \subseteq \mathrm{m}-\mathrm{Cl}(\mathrm{A})$ then $\mathrm{B}$ is a m-t set.

Proof: We note that $\mathrm{m}-\mathrm{Cl}(\mathrm{B}) \subseteq \mathrm{m}-\mathrm{Cl}(\mathrm{A})$.

So we have

$$
\begin{aligned}
\mathrm{m}-\operatorname{Int}(\mathrm{B}) & \subseteq \mathrm{m}-\operatorname{Int}(\mathrm{m}-\mathrm{Cl}(\mathrm{B})) \\
& \subseteq \mathrm{m}-\operatorname{Int}(\mathrm{m}-\mathrm{Cl}(\mathrm{A})) \\
& =\mathrm{m}-\operatorname{Int}(\mathrm{A}) \subseteq \mathrm{m}-\operatorname{Int}(\mathrm{B}) .
\end{aligned}
$$

Thus $\mathrm{m}-\operatorname{Int}(\mathrm{B})=\mathrm{m}-\operatorname{Int}(\mathrm{m}-\mathrm{Cl}(\mathrm{B}))$ and therefore $\mathrm{B}$ is a $\mathrm{m}-\mathrm{t}$ set.

Remark 3.2. The union of two $m-h$ sets need not be a m-h set. Refer Example 3.1, $\{a\}$ and $\{b\}$ are $m-h$ sets but $\{a, b\}$ is not m-h set.

Remark 3.3. Let $\left(X, m_{x}\right)$ have property $I$. Then the intersection of any two $m-h$ sets is a m-h set.

\section{Comparison}

Theorem 4.1. Any m-open set is an $m-A$ set.

Proof: $S=X \cap S$ where $X \in m-R C(X)$ and $S$ is m-open. The proof is completed.

Remark 4.1. The converse of Theorem 4.1 is not true. Refer Example 3.1, $\{b, c\}$ is $\mathrm{m}-\mathrm{A}$ set but not m-open.

Theorem 4.2. Any $m$-closed set is a $m$-t set.

Proof: Since $A=m-C l(A)$, m-Int $(A)=m-\operatorname{Int}(m-C l(A))$. The proof is completed.

Remark 4.2. The converse of Theorem 4.2 is not true. Refer Example 3.1, $\{\mathrm{a}\}$ is $\mathrm{m}$-t set but not m-closed.

Theorem 4.3. A regular m-open set is a m-t set.

Proof: Since $S=m-\operatorname{Int}(m-C l(S))$, $m-\operatorname{Int}(S)=m-\operatorname{Int}(m-C l(S))$.

The proof is completed.

Remark 4.3. The converse of Theorem 4.3 is not true. Refer Example 3.1, $\{c\}$ is a m-t set but not regular m-open.

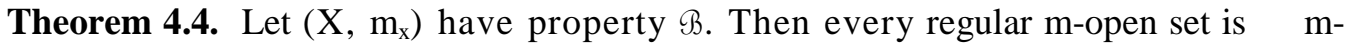
open.

Proof: Suppose $\mathrm{S}=\mathrm{m}-\mathrm{Int}(\mathrm{m}-\mathrm{Cl}(\mathrm{S}))$.

Then $\mathrm{m}-\operatorname{Int}(\mathrm{S})=\mathrm{m}-\operatorname{Int}(\mathrm{m}-\mathrm{Cl}(\mathrm{S}))$ and we have $\mathrm{S}=\mathrm{m}-\operatorname{Int}(\mathrm{S})$. 
Thus, $\mathrm{S}$ is m-open.

Remark 4.4. The converse of Theorem 4.4 is not true. Refer Example 3.1, $\{a, b\}$ is mopen but not regular m-open.

Theorem 4.5. Any $m-t$ set is $m-B$ set.

Proof: $\mathrm{S}=\mathrm{X} \cap \mathrm{S}$ where $\mathrm{X}$ is $\mathrm{m}$-open and $\mathrm{S}$ is $\mathrm{m}$ - $\mathrm{t}$ set. The proof is completed.

Remark 4.5. The converse of Theorem 4.5 is not true. Refer Example 3.2, $\{\mathrm{a}\}$ is a m-B set but not m-t set.

Theorem 4.6. Any m-open set is a $\mathrm{m}-\mathrm{B}$ set.

Proof: Since $\mathrm{S}=\mathrm{X} \cap \mathrm{S}$ where $\mathrm{S}$ is $\mathrm{m}$-open and $\mathrm{X}$ is regular m-open, by Theorem 4.3, $\mathrm{X}$ is $\mathrm{m}$-t set. The proof is completed.

Remark 4.6. The converse of Theorem 4.6 is not true. Refer Example 3.1, $\{\mathrm{c}\}$ is $\mathrm{m}-\mathrm{B}$ set but not m-open.

Theorem 4.7. A m-closed set is a $\mathrm{m}-\mathrm{B}$ set.

Proof: It follows from Theorem 4.2 and Theorem 4.5.

Theorem 4.8. Let $\left(\mathrm{X}, \mathrm{m}_{\mathrm{x}}\right)$ have property $\mathcal{B}$. Then every $\mathrm{m}$-A set is a $\mathrm{m}-\mathrm{B}$ set.

Proof: $\mathrm{S}=\mathrm{X} \cap \mathrm{S}$ where $\mathrm{X}$ is $\mathrm{m}$-open and $\mathrm{S}$ is regular $\mathrm{m}$-closed.

Since $\mathrm{S}$ is $\mathrm{m}$-closed, by Theorem $4.2, \mathrm{~S}$ is $\mathrm{m}$-t set. The proof is completed.

Remark 4.7. The converse of Theorem 4.8 is not true. Refer Example 3.1, $\{\mathrm{c}\}$ is $\mathrm{m}-\mathrm{B}$ set but not m-A set.

Theorem 4.9. Any $m-t$ set is $m-h$ set.

Proof: Since $\mathrm{m}-\operatorname{Int}(\mathrm{S})=\mathrm{m}-\mathrm{Int}(\mathrm{m}-\mathrm{Cl}(\mathrm{S}))$, $\mathrm{m}-\mathrm{Cl}(\mathrm{m}-\mathrm{Int}(\mathrm{S}))=\mathrm{m}-\mathrm{Cl}(\mathrm{m}-\mathrm{Int}(\mathrm{m}-\mathrm{Cl}(\mathrm{S})))$

implies $m-\operatorname{Int}(m-C l(m-\operatorname{Int}(\mathrm{S})))=\mathrm{m}-\operatorname{Int}(\mathrm{m}-\mathrm{Cl}(\mathrm{S}))=\mathrm{m}-\operatorname{Int}(\mathrm{S})$.

The proof is completed.

Remark 4.8. The converse of Theorem 4.9 is not true. Refer Example 3.3, $\{\mathrm{b}\}$ is $\mathrm{m}$-h set but not m-t set.

Theorem 4.10. Any $m-h$ set is $m-C$ set.

Proof: $\mathrm{S}=\mathrm{X} \cap \mathrm{S}$ where $\mathrm{X}$ is $\mathrm{m}$-open and $\mathrm{S}$ is $\mathrm{m}$-h set. The proof is completed.

Remark 4.9. The converse of Theorem 4.10 is not true. Refer Example 3.2, $\{a\}$ is $m-C$ set but not m-h set.

Theorem 4.11. Any $\mathrm{m}$-open set is $\mathrm{m}-\mathrm{C}$ set.

Proof: $\mathrm{S}=\mathrm{X} \cap \mathrm{S}$ where $\mathrm{X}$ is $\mathrm{m}$-h set and $\mathrm{S}$ is $\mathrm{m}$-open. The proof is completed. 


\section{Some Results on Decompositions of M-Continuity}

Remark 4.10. The converse of Theorem 4.11 is not true. Refer Example 3.1, $\{\mathrm{c}\}$ is $\mathrm{m}$ C set but not m-open.

Theorem 4.12. A $m-B$ set is $m-C$ set.

Proof: $\mathrm{S}=\mathrm{X} \cap \mathrm{S}$ where $\mathrm{X}$ is $\mathrm{m}$-open and $\mathrm{S}$ is $\mathrm{m}$-t set.

By Theorem 4.9, $\mathrm{S}$ is $\mathrm{m}-\mathrm{h}$ set. The proof is completed.

Remark 4.11. The converse of Theorem 4.12 is not true. Refer Example 3.3, $\{\mathrm{b}\}$ is m$\mathrm{C}$ set but not $\mathrm{m}-\mathrm{B}$ set.

Remark 4.12. A m-A set need not be m-semi-open as shown in the following example. Let $X=\{a, b, c\}$ and $m_{x}=\{\phi, X,\{a\},\{b\},\{a, b\},\{b, c\},\{a, c\}\}$. Then the sets in $\{\phi, X,\{a\},\{b\},\{c\},\{a, c\},\{b, c\}\}$ are called m-closed. We have $\{c\}$ is m-A set but not m-semi-open.

Remark 4.13. A m-semi-open set need not be $\mathrm{m}$-A set as shown in the following example.

Let $X=\{a, b, c\}$ and $m_{x}=\{\phi, X,\{a\}\}$. Then the sets in $\{\phi, X,\{b, c\}\}$ are called $m-$ closed. We have $\{a, b\}$ is m-semi-open but not $\mathrm{m}$-A set.

Remark 4.14. By the previous Theorems, Examples and Remarks, we obtain the following diagram:

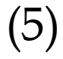

(6)
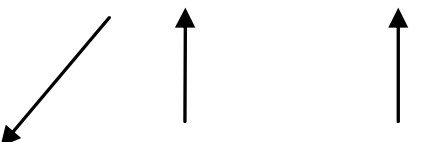

(1)

(2)
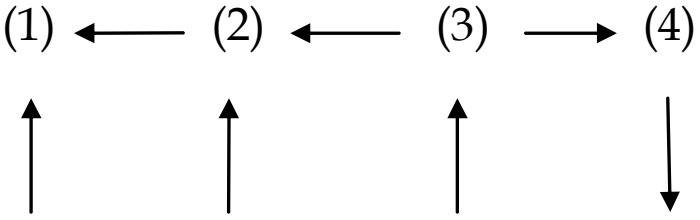

(7)

(8)

(9)

Here
(1) $=\mathrm{m}-\mathrm{C}$ set,
(4) $=\mathrm{m}-\alpha$-open set,
(7) $=\mathrm{m}-\mathrm{h} \mathrm{set}$,
(10) $=\mathrm{m}$-preopen set.

(2) = m-B set,

(3) = m-open set,

(5) $=\mathrm{m}-\mathrm{A}$ set,

(6) = m-semi-open set,

(8) $=\mathrm{m}-\mathrm{t}$ set,

(9) = regular m-open set,

\section{Decompositions of m-continuity}

Definition 5.1. Let $\mathrm{f}: \mathrm{X} \rightarrow \mathrm{Y}$ be a mapping where $\mathrm{X}$ has property $\mathcal{B}$. Then $\mathrm{f}$ is said to be M-continuous [14] if $\mathrm{f}^{-1}(\mathrm{~V})$ is $\mathrm{m}_{\mathrm{x}}$-open in $\mathrm{X}$ for every $\mathrm{m}_{\mathrm{y}}$-open set $\mathrm{V}$ in $\mathrm{Y}$. 
C.Loganathan, R.Vijaya Chandra and O.Ravi

We introduce new classes of mappings as follows:

Definition 5.2. Let $f: X \rightarrow Y$ be a mapping. Then $f$ is said to be

(i) M-A continuous if $f^{-1}(V)$ is M-A set in $X$ for every $m_{y}$-open set $V$ in $Y$,

(ii) M-B continuous if $\mathrm{f}^{-1}(\mathrm{~V})$ is $\mathrm{M}-\mathrm{B}$ set in $\mathrm{X}$ for every $\mathrm{m}_{\mathrm{y}}$-open set $\mathrm{V}$ in $\mathrm{Y}$,

(iii) $\mathrm{M}-\mathrm{C}$ continuous if $\mathrm{f}^{-1}(\mathrm{~V})$ is $\mathrm{m}-\mathrm{C}$ set in $\mathrm{X}$ for every $\mathrm{m}_{\mathrm{y}}$-open set $\mathrm{V}$ in $\mathrm{Y}$.

Theorem 5.1. Let $\left(X, m_{x}\right)$ have property $B$. Then a subset $S$ of $X$ is regular $m$ open if and only if it is both m-preopen and $\mathrm{m}$-t set.

Proof: Let $\mathrm{S}$ be a regular m-open.

By Theorem 4.3, $\mathrm{S}$ is $\mathrm{m}$-t set. Also by Theorem 4.4, $\mathrm{S}$ is m-open.

Thus, $\mathrm{S}$ is $\mathrm{m}$-preopen.

Conversely, let $\mathrm{S}$ be both $\mathrm{m}$-preopen and $\mathrm{m}$-t set.

Since $\mathrm{m}-\operatorname{Int}(\mathrm{S}) \subseteq \mathrm{S} \subseteq \mathrm{m}-\operatorname{Int}(\mathrm{m}-\mathrm{Cl}(\mathrm{S}))=\mathrm{m}-\operatorname{Int}(\mathrm{S}), \mathrm{S}=\mathrm{m}-\operatorname{Int}(\mathrm{m}-\mathrm{Cl}(\mathrm{S}))$.

Hence, $\mathrm{S}$ is regular $\mathrm{m}$-open.

Theorem 5.2. Let $\left(X, m_{x}\right)$ have property $B$ and property $I$. Then a subset $S$ of $X$ is $\mathrm{m}$-open if and only if it is both $\mathrm{m}$ - $\alpha$-open and $\mathrm{m}$-A set.

Proof: Let $\mathrm{S}$ be an m-open. Then $\mathrm{S}$ is $\mathrm{m}-\alpha$-open and by Theorem $4.1, \mathrm{~S}$ is $\mathrm{m}-\mathrm{A}$ set.

Conversely, let $\mathrm{S}$ be both $\mathrm{m}-\alpha$-open and $\mathrm{m}-\mathrm{A}$ set.

Since $S$ is $\mathrm{m}-\mathrm{A}$ set, $\mathrm{S}=\mathrm{M} \cap \mathrm{N}$ where $\mathrm{M}$ is $\mathrm{m}$-open and $\mathrm{N} \in \mathrm{m}-\mathrm{RC}(\mathrm{X})$.

Since $S$ is $m-\alpha$-open,

$$
\begin{aligned}
\mathrm{M} \cap \mathrm{N} & \subseteq \mathrm{m}-\operatorname{Int}(\mathrm{m}-\mathrm{Cl}(\mathrm{m}-\operatorname{Int}(\mathrm{M} \cap \mathrm{N}))) \\
& \subseteq \mathrm{m}-\operatorname{Int}(\mathrm{m}-\mathrm{Cl}(\mathrm{m}-\operatorname{Int}(\mathrm{M}) \cap \mathrm{m}-\operatorname{Int}(\mathrm{N}))) \\
& =\mathrm{m}-\operatorname{Int}(\mathrm{m}-\mathrm{Cl}(\mathrm{M} \cap \mathrm{m}-\operatorname{Int}(\mathrm{N})))
\end{aligned}
$$

as $\mathrm{M}$ is $\mathrm{m}$-open $\subseteq \mathrm{m}-\operatorname{Int}(\mathrm{m}-\mathrm{Cl}(\mathrm{M}) \cap \mathrm{m}-\mathrm{Cl}(\mathrm{m}-\mathrm{Int}(\mathrm{N})))$

$$
=\mathrm{m}-\mathrm{Int}(\mathrm{m}-\mathrm{Cl}(\mathrm{M}) \cap \mathrm{N})
$$

As $\quad \mathrm{N} \in \mathrm{m}-\mathrm{RC}(\mathrm{X}) \subseteq \mathrm{m}-\operatorname{Int}(\mathrm{m}-\mathrm{Cl}(\mathrm{M})) \cap \mathrm{m}-\operatorname{Int}(\mathrm{N})$

Since $\mathrm{M} \subset \mathrm{m}-\mathrm{Int}(\mathrm{m}-\mathrm{Cl}(\mathrm{M}))$, by $(1)$

$$
\begin{aligned}
\mathrm{S} & =\mathrm{M} \cap \mathrm{N}=(\mathrm{M} \cap \mathrm{N}) \cap \mathrm{M} \\
& \subseteq(\mathrm{m}-\operatorname{Int}(\mathrm{m}-\mathrm{Cl}(\mathrm{M})) \cap \mathrm{m}-\operatorname{Int}(\mathrm{N})) \cap \mathrm{M} \\
& =\mathrm{M} \cap \mathrm{m}-\mathrm{Int}(\mathrm{N}) \\
& =\mathrm{m}-\operatorname{Int}(\mathrm{M} \cap \mathrm{N}) \text { by property } \mathrm{I}=\mathrm{m}-\operatorname{Int}(\mathrm{S}) .
\end{aligned}
$$

Therefore, $S \subseteq \mathrm{m}$-Int(S). But $\mathrm{m}-\operatorname{Int}(\mathrm{S}) \subseteq \mathrm{S}$.

Hence, $\mathrm{S}$ is $\mathrm{m}$-open.

Theorem 5.3. Let $\left(X, m_{x}\right)$ have property $\mathcal{B}$ and property $I$. Then a subset $S$ of $X$ is $\mathrm{m}$-open if and only if it is both $\mathrm{m}$ - $\alpha$-open and $\mathrm{m}$-B set.

Proof: Let $\mathrm{S}$ be an $\mathrm{m}$-open. Then $\mathrm{S}$ is $\mathrm{m}$ - $\alpha$-open. Also, by Theorem $4.6, \mathrm{~S}$ is $\mathrm{m}-\mathrm{B}$ set. Conversely, let $\mathrm{S}$ be both $\mathrm{m}-\alpha$-open and $\mathrm{m}-\mathrm{B}$ set.

Since $\mathrm{S}$ is $\mathrm{m}-\mathrm{B}$ set, $\mathrm{S}=\mathrm{X} \cap \mathrm{S}$ where $\mathrm{X}$ is $\mathrm{m}$-open and $\mathrm{S}$ is $\mathrm{m}$-t set.

Then $\mathrm{S}=\mathrm{X} \cap \mathrm{S} \subseteq \mathrm{X} \cap \mathrm{m}$-Int(m-Cl(S)) (as $\mathrm{S}$ is $\mathrm{m}$-preopen) $=\mathrm{X} \cap \mathrm{m}-\operatorname{Int}(\mathrm{S})$ (as $\mathrm{S}$ is $\mathrm{m}-\mathrm{t}$ set).

We have $S \subseteq X \cap m-I n t(S)$. 
Some Results on Decompositions of M-Continuity

Hence $\mathrm{S} \subseteq \mathrm{m}$-Int $(\mathrm{X} \cap \mathrm{S})$ by property $\mathrm{I}$ and $\mathrm{S} \subseteq \mathrm{m}$-Int $(\mathrm{S})$.

But always $\mathrm{m}-\operatorname{Int}(\mathrm{S}) \subseteq \mathrm{S}$. Thus $\mathrm{S}=\mathrm{m}$ - $\operatorname{Int}(\mathrm{S})$ and by property $\mathcal{B}, \mathrm{S}$ is $\mathrm{m}$-open.

Theorem 5.4. Let $\left(X, m_{x}\right)$ have property $B$ and property $I$. Then a subset $S$ of $X$ is $\mathrm{m}$-open if and only if it is both $\mathrm{m}-\alpha$-open and $\mathrm{m}$ - $\mathrm{C}$ set.

Proof: Let $\mathrm{S}$ be an m-open in $\mathrm{X}$. Then $\mathrm{S}$ is $\mathrm{m}-\alpha$-open and by Theorem $4.11, \mathrm{~S}$ is $\mathrm{m}-\mathrm{C}$ set.

Conversely, let $\mathrm{S}$ be both $\mathrm{m}$ - $\alpha$-open and $\mathrm{m}-\mathrm{C}$ set.

Since $\mathrm{S}$ is $\mathrm{m}-\mathrm{C}$ set, $\mathrm{S}=\mathrm{M} \cap \mathrm{N}$ where $\mathrm{M}$ is $\mathrm{m}$-open and $\mathrm{N}$ is $\mathrm{m}-\mathrm{h}$ set.

Since $S$ is $\mathrm{m}-\alpha$-open set,

$$
\begin{aligned}
\mathrm{S} & \subseteq \mathrm{m}-\operatorname{Int}(\mathrm{m}-\mathrm{Cl}(\mathrm{m}-\operatorname{Int}(\mathrm{S}))) \\
& =\mathrm{m}-\operatorname{Int}(\mathrm{m}-\mathrm{Cl}(\mathrm{m}-\operatorname{Int}(\mathrm{M}))) \cap \mathrm{m}-\operatorname{Int}(\mathrm{m}-\mathrm{Cl}(\mathrm{m}-\operatorname{Int}(\mathrm{N}))) \\
& =\mathrm{m}-\operatorname{Int}(\mathrm{m}-\mathrm{Cl}(\mathrm{M})) \cap \mathrm{m}-\operatorname{Int}(\mathrm{N})(\text { as } \mathrm{M} \text { is m-open and } \mathrm{N} \text { is } \mathrm{m}-\mathrm{h} \text { set }) \\
\text { Now } \mathrm{S} & =\mathrm{M} \cap \mathrm{N} \\
& =\mathrm{M} \cap(\mathrm{M} \cap \mathrm{N}) \\
& =\mathrm{M} \cap \mathrm{S} \\
& \subset \mathrm{M} \cap(\mathrm{m}-\operatorname{Int}(\mathrm{m}-\mathrm{Cl}(\mathrm{M})) \cap \mathrm{m}-\operatorname{Int}(\mathrm{N})) \\
& =\mathrm{M} \cap \mathrm{m}-\operatorname{Int}(\mathrm{N})(\operatorname{as~} \mathrm{M} \subseteq \mathrm{m}-\operatorname{Int}(\mathrm{m}-\mathrm{Cl}(\mathrm{M}))) \\
& =\mathrm{m}-\operatorname{Int}(\mathrm{M} \cap \mathrm{N})(\text { by property } \mathrm{I})=\mathrm{m}-\operatorname{Int}(\mathrm{S})
\end{aligned}
$$

Thus, $\mathrm{S} \subseteq \mathrm{m}$-Int $(\mathrm{S})$ and $\mathrm{m}-\operatorname{Int}(\mathrm{S}) \subseteq \mathrm{S}$.

Hence, by property $\mathcal{B}, \mathrm{S}$ is m-open.

Theorem 5.5. Let $\left(X, m_{x}\right)$ have property $B$ and property $I$ and $f: X \rightarrow Y$ be a mapping. Then $\mathrm{f}$ is M-continuous if and only if

(i) it is $\mathrm{M}-\alpha$-continuous and $\mathrm{M}-\mathrm{A}$ continuous.

(ii)it is $\mathrm{M}-\alpha-\mathrm{-continuous}$ and $\mathrm{M}-\mathrm{B}$ continuous.

(iii) it is $\mathrm{M}-\alpha$-continuous and $\mathrm{M}-\mathrm{C}$ continuous.

Proof: It is the decompositions of M-continuity from Theorems 5.2, 5.3 and 5.4.

Remark 5.1. In the above four theorems, both properties are used and so the above four theorems are nothing but topological results.

\section{REFERENCES}

1. P.Bhattacharyya and B.K.Lahar, Semi-generalized closed sets in topology, Indian J. Math., 29 (1987) 375-382.

2. F.Cammaroto and T.Noir, On $\lambda \mathrm{m}$-sets and related topological spaces, Acta Math. Hungar., 109(3) (2005) 261-279.

3. J.Dontchev and M.Przemski, On the various decompositions of continuous and some weakly continuous functions, Acta Math. Hungar., 71(1-2) (1996) 109-120.

4. M.Ganster and I.L.Reilly, A decomposition of continuity, Acta Math. Hungar., 56 (1990) 299-301.

5. K.Geetha and M.Vigneshwaran, On contra $\mathrm{p}^{*} \mathrm{~g} \alpha$-continuous functions and strongly $\mathrm{p}^{*} \mathrm{~g} \alpha$-closed spaces, Annals of Pure and Applied Mathematics, 12(2) (2016) 197-210.

6. E.Hatir and T.Noiri, On decomposition of continuity via idealization, Acta Math. Hungar., 96 (2002) 341-349. 
C.Loganathan, R.Vijaya Chandra and O.Ravi

7. E.Hatir and T.Noiri, Decomposition of continuity and complete continuity, Acta Math. Hungarica, 113 (2006) 281-287.

8. E.Hatir and T.Noiri, Decompositions of continuity and complete continuity, Indian J. Pure Appl. Math., 33(5) (2002) 755-760.

9. E.Hatir and T.Noiri, Strong C sets and decompositions of continuity, Acta Math. Hungar., 94(4) (2002) 281-287.

10. C.Loganathan, R.Vijaya Chandra and O.Ravi, Between closed sets and g $\omega$-closed sets, IOSR Journal of Mathematics, 13 (2017) 9-15.

11. C.Loganathan, R.Vijaya Chandra and O.Ravi, $\mathrm{m}^{*}$-operfect sets and $\alpha$-m*-closed sets, Annals of Pure and Applied Mathematics, 13(1) (2017) 131-141.

12. N.Meenakumari and T.Indira, $\mathrm{r}^{*} \mathrm{~g}^{*}$-closed sets in topological spaces, Annals of Pure and Applied Mathematics, 6(2) (2014) 125-132.

13. O.Njastad, On some classes of nearly open sets, Pacific Jour. Math., 15 (1965) 961970.

14. V.Popa and T.Noiri, A decomposition of m-continuity, Bul. Uni. Petrol-Gaze din Ploisti, LXII(2) (2010) 46-53.

15. V.Popa and T.Noiri, On M-continuous functions, Anal. Univ. Dunarea de Jos Galati, Ser. Mat. Fiz. Mec. Tecor., 18 (23) (2000) 31-41.

16. J.Tong, On decomposition of continuity in topological spaces, Acta Math. Hungar., 54(1-2) (1989) 51-55.

17. J.Tong, A decomposition of continuity, Acta Math. Hungar., 48 (1-2) (1986) 11-15. 